\title{
Risk Assessment of Horizontal Wet Etching Equipment System in Manufacturing Plant Industry
}

\author{
Nor'ain Mohd Ramli ${ }^{1,2}$, Siti Aslina Hussain ${ }^{1,2 *}$ \\ ${ }^{1}$ Department of Chemical and Environmental Engineering, Faculty of Engineering, Universiti Putra Malaysia, \\ 43400 UPM Serdang, Selangor Darul Ehsan. \\ ${ }^{2}$ Safety Engineering Interest Group (SEIG), Department of Chemical and Environmental Engineering, Faculty of \\ Engineering, Universiti Putra Malaysia, 43400 UPM Serdang, Selangor, Malaysia \\ *Corresponding author: aslina@upm.edu.my
}

\section{Article History}

Received: March 04, 2020

Received in revised form: June 01, 2020

Accepted: June 03, 2020

Published Online: June 30, 2020

\begin{abstract}
Maintenance is one of the important roles in the high technology manufacturing industry. It is related to the key perfomance factors of the company such as quality, productivity, and cost. To achieve thesefactors, a relia bility plan should be implemented which helps to maximise production value by implementing successful a sset maintenance. This resea rch project aims to focus on the critical process equipment known as Horizontal Wet Etching Equipment (HWEE) used in the wet etching process. The components in the HWEE system were identified by referring to the process and instrumentation dia gram (P\&ID) of the equipment and were categorised in different modes. Data on mean time to repair (MTTR) and mean time between repairs (MTBF) were collected based on previous company records. The data were analysed using MAROS software. Failure Mode and Effect Analysis (FMEA) was done to understand the risk of each of the components. The result shows that piping and gearbox have the highest RPN with 126 and 105, respectively. This study helps to identify critical components and is able to help the company to improve equipment reliability and reducemaintenance cost. Corrective action can be implemented to reduce the RPN for both components. Thus, it would help the industry to increase the key performance and become more competitive in the business environment.
\end{abstract}

Keywords: Maintenance; Reliability;HorizontalWet Etching Process; Key Performance;Failure Mode andEffect Analysis.

\subsection{INTRODUCTION}

The high technology manufacturing industry involves processes of converting raw materials or parts into finished goods that can be sold in wholesale or retail markets or exported for sale in other countries. Ba sically, it is driven by the desire to produce sa leable finished products at the lowest possible cost while still maintaining a cceptable standards of quality, functionality and timeliness. There are four basic elements of an idealised process in a high technology manufacturing plant. These are product design, process design, shop floor production, and business process. Currently, the high technology manufacturing plant industry is growing and expanding world wide.

An example of a high technology manufacturing pla nt is the solar photovoltaic (PV) and semiconductor industry which is one of the key economic industries in the world. Solar PV is a technology that uses the basic properties of semiconductor materials to transform solar energy into semiconducting materials. There are many of process steps involved in the large-scale high technology manufacturing plant industry (i.e. solar PV industry). This process equipment deals with a lot of flammable, spontaneous combustion, toxic corrosive, special ga ses and chemicals [1] [2] [10]. One of the critical process steps is the wet etching process.

Wet etching refers to the process by which material is removed from a wafer either from the silicon substrate itself or from the 
film or layer of material on the wafer. This process involves various chemicals or etchants to remove the unwanted material from the wa fers. Most wet etching processes in the high technology manufacturing plant industry entail potentially hazardous phenomena including overflow, boiling, bubbling, two-phase swelling, temperature rise, and autocatalytic behaviour [3] [9]. The cause of these hazardous phenomena is related to the strategy of maintenance implemented in the plant.

Plant maintenance should be conducted properly as it plays a vital role in production management. Breakdowns will create problems such as production loss, material loss, need for overtime, need for subcontracting work, and temporary work shortage [4] [7] [11]. A reliability plan should be implemented in order to achieve these key performance factors. It is a roadmap that helps to ma ximise production value by implementing successful asset maintenance [5].

In reliability, there are three terms which are always used; maintainability, a vailability, and failure. Technical maintenance stra tegies can be divided into several categories; breakdown or corrective run to failure maintenance, preventive maintenance $(\mathrm{PM})$, planned maintenance, proactive maintenance $(\mathrm{PrM})$, condition-based maintenance $(\mathrm{CbM})$, design-out maintenance and reliability centred maintenance (RCM).

Yaasad and his tea m used the Reliability Centred Maintenance model (RCM) to optimise the maintenance management of equipment while Vishnu and Regikumar conducted a study on Reliability Centred Maintenance (RCM) where the result showed that all critical equipment needs a preventive maintenance strategy rather than scheduled maintenance and breakdown maintenance [11] [12]. RCM is a systematic method to maintain a balance between preventive and corrective maintenance. It a lso can be characterised by maintaining system functions, identifying failure modes, prioritising functions, and choosing efficient maintenance. The main objective of RCM is to reduce the maintenance cost by focusing on the most important functions of the system.

There are many methods used to improve the reliability of maintenance such as Preventive Maintenance (PM) and Corrective Maintenance (CM) [13]. However, there are limitations to the stated methods for the current study. For example, they lead to excessive costs of maintenance due to an improper maintenance strategy. The most reliable and suitable method to improve the reliability of equipment is by conducting FMEA. Mauro and other researchers had used the FMEA approach in order to optimise the maintenance plan of photov oltaic (PV) systems. Their finding can help to improve various failure modes which mostly affect production [6]. Conducting FMEA may also help in minimising operating costs such as maintenance cost and a void any major downtime that could cause production interruption.

In this resea rch study, FMEA will be used as a method to conduct a risk assessment of the critical process equipment known as Horizontal Wet Etching Equipment (HWEE) used in the wet etching process. The process was identified by referring to the process and instrumentation diagram (P\&ID) sy stem from industry. FMEA is a tool that helps to identify critical components in equipment and is able to prevent any sa fety issues such as chemical and gas ex posure or explosion.

\subsection{METHODOLOGY}

A reliability a ssessment of Horizontal Wet Etching Equipment (HWEE) was carried out to understand the consistency of the equipment in meeting equipment design and requirement and also to prevent production losses. Critical components were identified in the HWEE system by referring to the Process a nd Instrumentation Dia gram(P\&ID) as shown in Figure 1. Mean Time To Repair (MTTR) and Mean Time Between Failure (MTBF) data were taken from the Manufacturing Execution System (MES) between 2017 to 2018. MTTR data refers to the average time required to troubleshoot and repair failed equipment while MTBF data is the a verage time between equipment breakdown. MAROS software [14] was used for this study as it is able to calculate the reliability of the equipment based on the components identified. The software helps to analyse and develop an a naly sis of the reliability, a vailability, and maintainability of a system or equipment. Figure 2 shows the MAROS software interface. Figure 3 shows the step flow to conduct the reliability assessment [8]: 
Nor'ain Mohd Ramli \& Siti Aslina Hussain /JEST -Joumal of Energy and Safety Technology. vol. 3, no.1 (2020):01-11

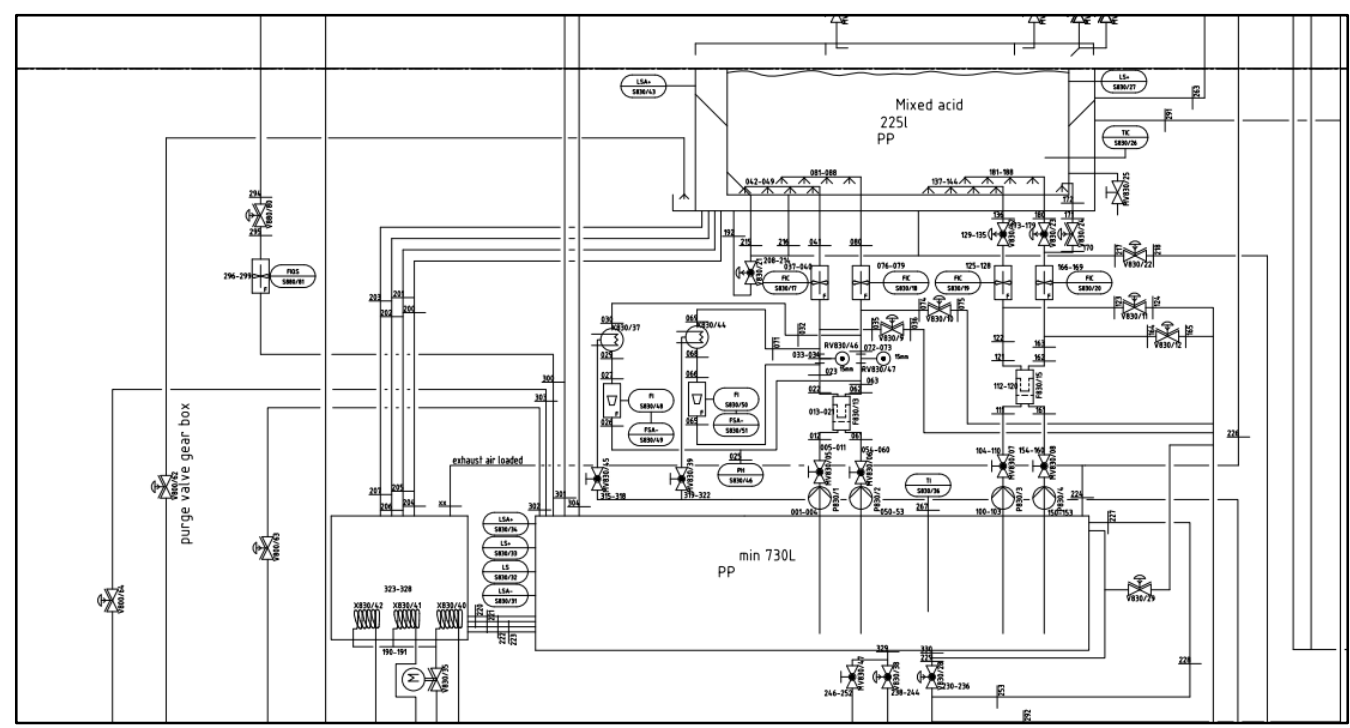

Figure 1 P\&ID of HWEE Sy stem

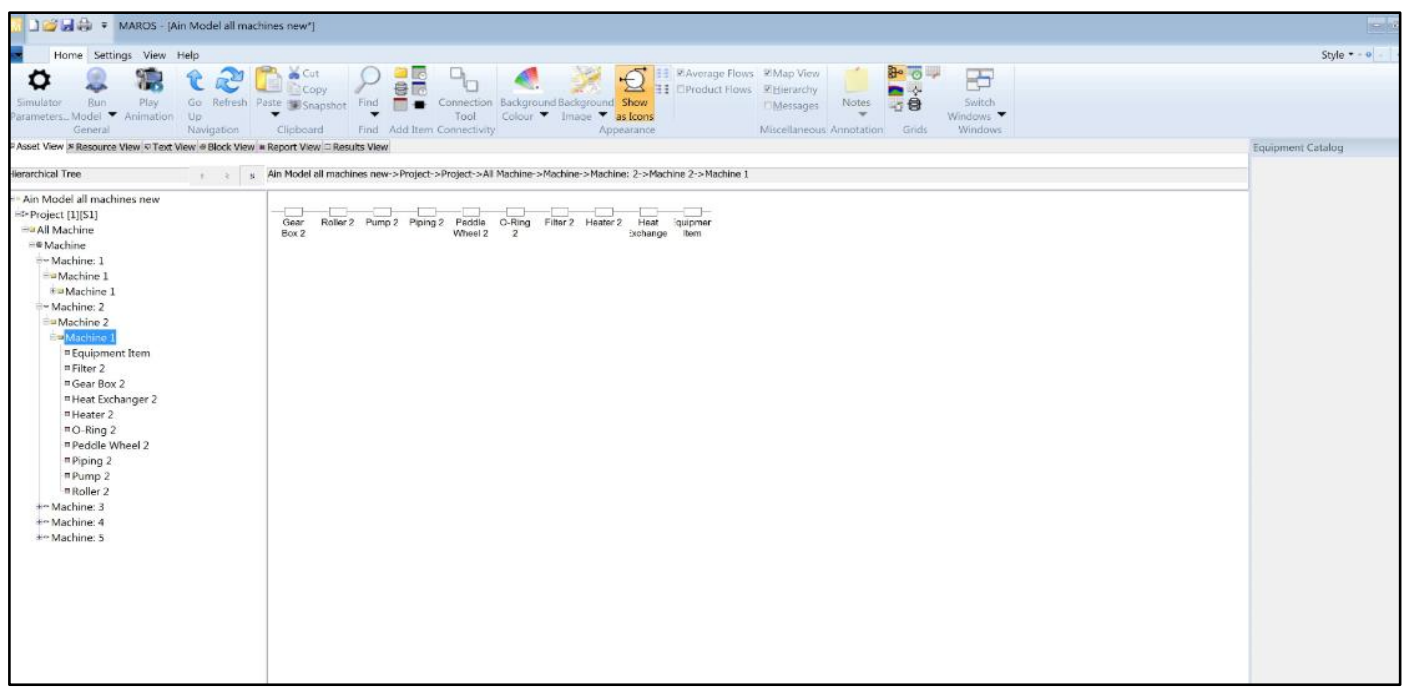

Figure 2 Interface of MAROS Software 


\section{Systemselection}

- HorizontalWet Etching Equipment (HWEE)' sys tem

Identify criticalcomponent in the HWEE's systemby referring to Process \& Instrumentation(P\&ID)

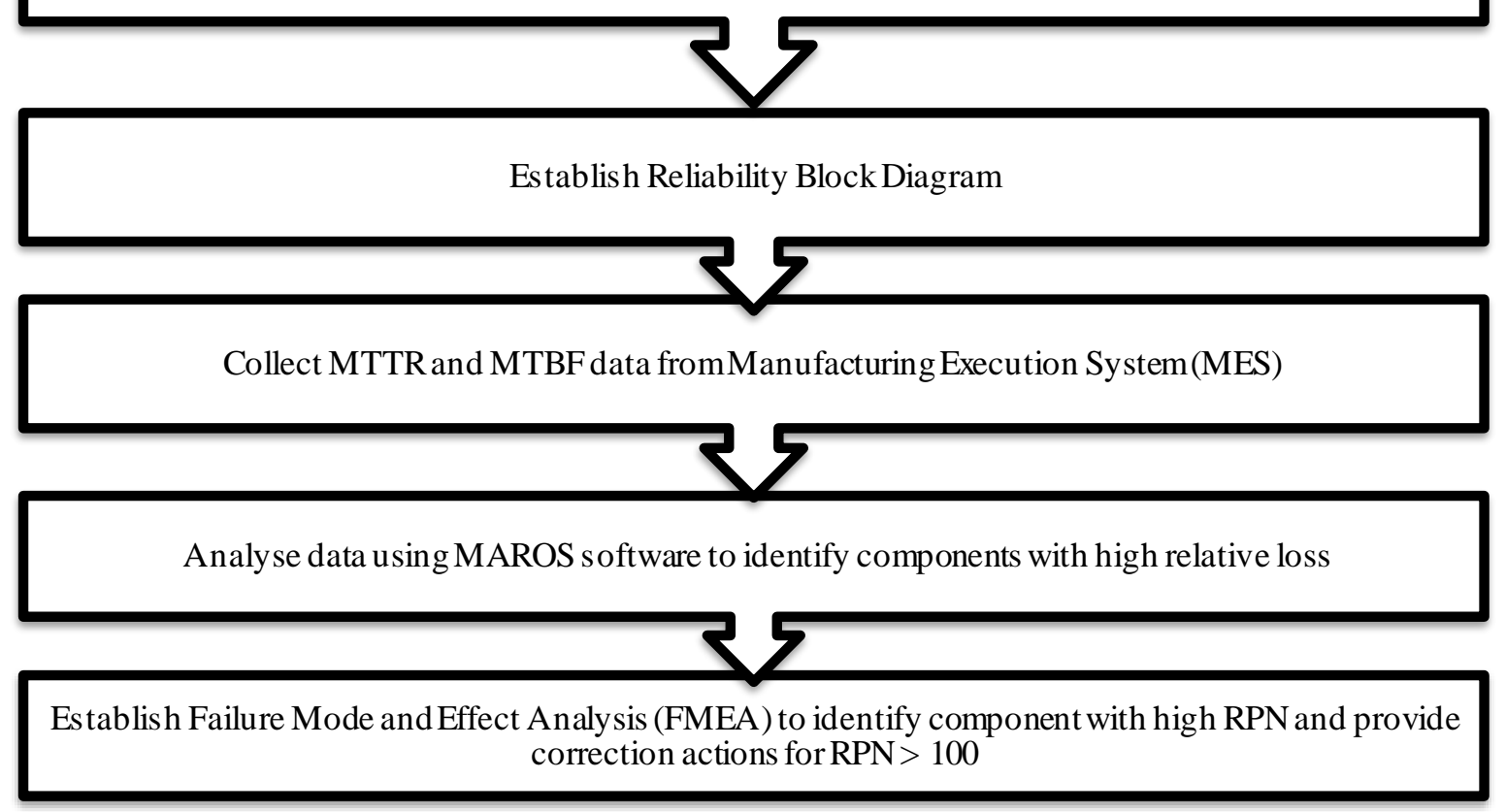

Figure 3 Step flow to conduct reliability assessment

FMEA was established based on the critical components in the HWEE system. The criticality using FMEA is defined by the Risk Priority Number (RPN) which is the combination of ratings; severity of the effects (S), occurrence (O), a nd detection (D) as mentioned in Table 1, Table 2, and Table 3, respectively. Severity relates to the seriousness of the end effect of a component failure, occurrence is the frequency that a malfunctioning event is likely to occur, and detection is the likelihood to detect a potentialfailure situation before it occurs. RPN is calculated using Equation 1:

$$
\mathrm{R} P N: S \times O \times D
$$

Table 1 The Severity ra nking criteria

\begin{tabular}{cl}
\hline RANK & \multicolumn{1}{c}{ DESCRIPTION } \\
\hline $\mathbf{9 - 1 0}$ & $\begin{array}{l}\text { Failure will occur with warning. } \\
\text { Safety issue with warning. } \\
100 \% \text { product recall after installation. }\end{array}$ \\
\hline $\mathbf{7 - 8}$ & $\begin{array}{l}\text { Customer dissatisfied. } \\
100 \% \text { product recall before installation. }\end{array}$ \\
\hline $\mathbf{5 - 6}$ & Customer experiences some dissatisfaction. \\
\hline $\mathbf{4}$ & Defect noticed by most customers $(>75 \%)$. \\
\hline $\mathbf{3}$ & Defect noticed by average customers $(\sim 50 \%)$. \\
\hline $\mathbf{2}$ & Defect noticed by discriminating customers $(<25 \%)$. \\
\hline $\mathbf{1}$ & No nuisance. \\
\hline
\end{tabular}


Table 2 The Occurrence ranking criteria

\begin{tabular}{cl}
\hline RANK & \multicolumn{1}{c}{ DESCRIPTION } \\
\hline $\mathbf{9 - 1 0}$ & Very high: Failure is almost inevitable. \\
\hline $\mathbf{7 - 8}$ & High: Generally associated with processes similar to previous processes that have often failed. \\
\hline $\mathbf{4 - 6}$ & $\begin{array}{l}\text { Moderate: Generally associated with processes similar to previous processes which have experienced occasional } \\
\text { failures, but no in major proportions. }\end{array}$ \\
\hline $\mathbf{3}$ & Low: Isolated failures associated with similar processes. \\
\hline $\mathbf{2}$ & Very Low: Only isolated failures associated with almost identical processes. \\
\hline $\mathbf{1}$ & Remote: Failure is unlikely. No failures ever associated with almost identical processes.
\end{tabular}

Table 3 The Detection ranking criteria

\begin{tabular}{|c|c|}
\hline RANK & DESCRIPTION \\
\hline 10 & No known controls available to detect failure mode. \\
\hline 9 & Weekly monitoring schedule is in place, but there are no available prevention controls. \\
\hline 8 & Daily monitoring schedule is in place, but there are no available prevention controls \\
\hline 7 & Daily monitoring schedule is in place with regular PM monitoring. \\
\hline 6 & Reliability Modeling System used (Equipment Monitoring). \\
\hline 5 & Failure analysis tools employed regularly, such as vibration analyzer, thermal scanner, oscilloscope, etc. \\
\hline 4 & Controlled and monitored set-up with first article check (for set-up causes only). \\
\hline 3 & $\begin{array}{l}\text { Potential cause has a real-time feedback; the correction has a human intervention. Real-time feedback means that } \\
\text { there is a built-in alarm (audible or visual display). }\end{array}$ \\
\hline 2 & Potential cause has a real-time feedback; the machine automatically corrects the error. \\
\hline 1 & The system has built-in Fault Detection Controls. \\
\hline
\end{tabular}

\subsection{RESULTS AND DISCUSSION}

There were eight critical components identified in the system; gearbox, roller, pump, piping, paddle wheel, O-ring, filter, and heat exchanger. These components were categorised based on two different modes, which are critical and degraded. Critical mode is referring to the $100 \%$ losses to production, and degraded mode is referring to if the impact is only some portion (i.e. $50 \%$ ) of the production loss. The selection of the percentage is based on the critica lity of the components that will affect the performance or reliability of the equipment that leads to major downtime in production. The main eight components are as shown in Figure 4 and known as the Reliability Block Dia gram (RBD) of the HWEE system.

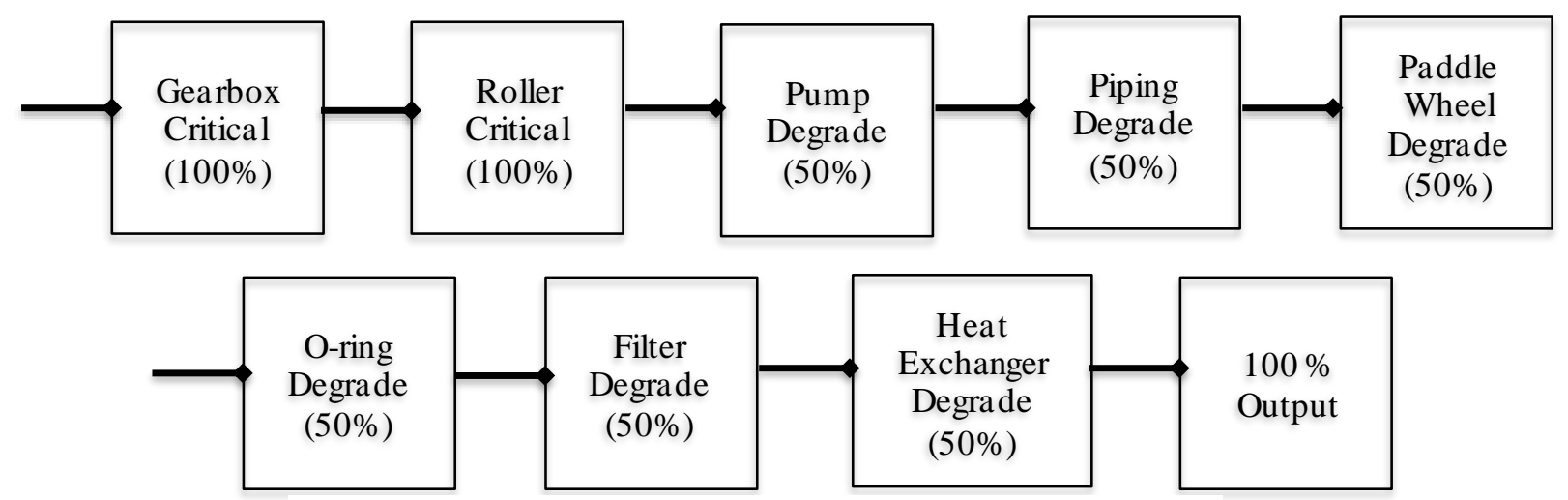

Figure 4 Reliability Block Dia gram (RBD) of HWEE sy stem 
Based on the RBD, the gearbox and filter were identified as critical while the roller, pump, piping, paddle wheel, O-ring, and heat exchanger were identified as degraded. The identification of the components in the HWEE system enables a reliability a ssessment to be carried out. Table 4 shows the MTBF and MTTR data of the HWEE components from the Manufacturing Execution System (MES) record.

Table 4 MTBF and MTTR data of the HWEEcomponents

\begin{tabular}{cccc}
\hline Component & Mode & MTBF (days) & MTTR (hour) \\
\hline Gearbox & Critical & 90 & 14.01 \\
Roller & Critical & 180 & 9.79 \\
Pump & Degraded & 290 & 2.10 \\
Piping & Degraded & 60 & 15.75 \\
Paddle Wheel & Degraded & 10 & 0.63 \\
O-ring & Degraded & 270 & 14.73 \\
Filter & Degraded & 60 & 0.63 \\
Heat Exchanger & Degraded & 200 & 4.50 \\
\hline
\end{tabular}

MTBF is a basic measure of a system's reliability. MTTR is the expected time to recover a system from a failure. This includes the time to diagnose the problem by an onsite technician or the time it takes to physically repair the system. The MTBF and MTTR data show that the pump has the highest MTBF number at 290 days while the paddle wheel has the lowest MTBF at only 10 days. This means that the pump has a longer reliability compared to the paddle wheel a sump maintenance has been done by repla cing the impeller material from PP to PVDF. For MTTR, piping has the highest number at 15.75 hours and paddle wheel and filter have the lowest MTTR number a t only 0.63 hours.

From the MAROS simulation [14], the components with high relative loss a re piping and gearbox with $31.81 \%$ and $29.79 \%$ rela tive loss, respectively, as depicted in Figure 5. Piping has the highest relative loss due to a leaking issue which causes production downtime to carry outrepairs. The leak only occurs at the welding joint area on thepiping. The component with low relative loss is the pump with $0.83 \%$ relative loss. This is because the design of the pump is compatible with the operating parameters and process design of the HWEE system. The impeller used in the pump is madefrom PVDF.

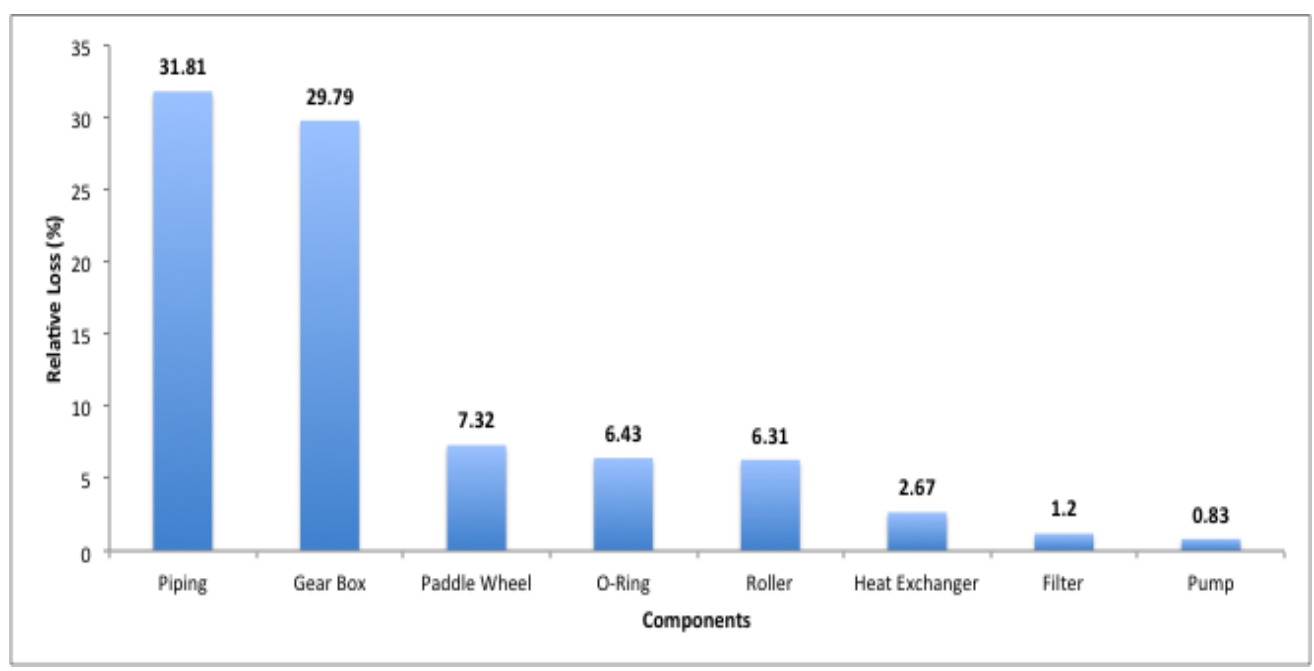

Figure 5 Invidual component in HWEE system based on relative loss

Failure mode and effect analysis (FMEA) can beestablished in order to analyse the risk and failure modes from the components listed. All the information from MAROS software [14] can be used to determine the impact each failure would have on the product; thus, improvements can be made to the product design and relia bility of the system. Table 5 shows the FMEA for each component in the HWEE system. Only two components i.e. piping \#1 and gea rbox \#3 show RPN>100 and corrective actions 
have been taken to improve the maintenance of the system. There are eight components in the HWEE system and total of 17 failure modes havebeen identified for each of the components.

Table 5 FMEA on HWEE components

\begin{tabular}{|c|c|c|c|c|c|c|c|c|c|}
\hline \multirow[b]{2}{*}{ Component } & \multirow[b]{2}{*}{$\begin{array}{l}\text { Potential } \\
\text { Failure } \\
\text { Mode \# }\end{array}$} & \multirow[b]{2}{*}{$\begin{array}{c}\text { Potential Failure } \\
\text { Mode }\end{array}$} & \multirow[b]{2}{*}{$\begin{array}{c}\text { Potential Cause(s)/ } \\
\text { Mechanism(s) of } \\
\text { Failure }\end{array}$} & \multicolumn{2}{|c|}{ Current Design Controls } & \multirow[b]{2}{*}{ : } & \multirow[b]{2}{*}{ 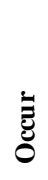 } & \multirow[b]{2}{*}{ 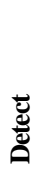 } & \multirow[b]{2}{*}{ 亩 } \\
\hline & & & & Prevent & Detect & & & & \\
\hline \multirow{5}{*}{ Roller } & $\# 5$ & \multirow{3}{*}{ Broken roller } & $\begin{array}{l}\text { Friction between the } \\
\text { rollers }\end{array}$ & None & Visual inspection & \multirow{3}{*}{7} & 2 & 7 & 98 \\
\hline & \#6 & & Worn out roller & None & Visual inspection & & 2 & 7 & 98 \\
\hline & $\# 7$ & & $\begin{array}{l}\text { Manual handling of the } \\
\text { roller by technicians }\end{array}$ & None & Visual inspection & & 2 & 7 & 98 \\
\hline & $\# 8$ & Bend roller & $\begin{array}{l}\text { Expose to high vapor of } \\
\qquad \mathrm{H}_{2} \mathrm{O}_{2}\end{array}$ & Auto drain system & Visual inspection & 7 & 1 & 7 & 49 \\
\hline & $\# 9$ & $\begin{array}{l}\text { Inaccurate dimension } \\
\text { of roller }\end{array}$ & Fabrication issue & None & $\begin{array}{l}\text { Visual inspection } \\
\text { using roller jig }\end{array}$ & 7 & 2 & 5 & 70 \\
\hline \multirow{2}{*}{ Pump } & $\# 10$ & Low flowrate & Broken impeller & $\begin{array}{l}\text { Change the } \\
\text { impeller material } \\
\text { from PP to PVDF }\end{array}$ & $\begin{array}{l}\text { Machine real time } \\
\text { feedback: Alarm on } \\
\text { low flowrate }\end{array}$ & 5 & 2 & 3 & 30 \\
\hline & $\# 11$ & $\begin{array}{l}\text { Low level of chemical } \\
\text { in the process bath }\end{array}$ & Broken impeller & $\begin{array}{l}\text { Change the } \\
\text { impeller material } \\
\text { from PP to PVDF }\end{array}$ & $\begin{array}{l}\text { Machine real time } \\
\text { feedback: Alarm on } \\
\text { low flowrate }\end{array}$ & 5 & 2 & 3 & 30 \\
\hline $\begin{array}{l}\text { Paddle } \\
\text { wheel }\end{array}$ & $\# 12$ & $\begin{array}{l}\text { Inaccurate reading of } \\
\text { actual flowrate }\end{array}$ & Broken blade & None & $\begin{array}{l}\text { Machine real time } \\
\text { feedback: Alarm on } \\
\text { low flowrate }\end{array}$ & 4 & 2 & 3 & 24 \\
\hline O-ring & $\# 13$ & $\begin{array}{c}\text { Degradation of roller } \\
\text { O-ring }\end{array}$ & $\begin{array}{c}\text { Mixing of incompatible } \\
\text { O-ring in material the } \\
\text { modules }\end{array}$ & None & Visual inspection & 7 & 2 & 7 & 98 \\
\hline \multirow{2}{*}{ Filter } & $\# 14$ & \multirow{2}{*}{ Low flow circulation } & Filter clogged & $\begin{array}{l}\text { Scheduled } \\
\text { replacement of } \\
\text { filter }\end{array}$ & $\begin{array}{l}\text { Machine real time } \\
\text { feedback: Alarm on } \\
\text { low flowrate }\end{array}$ & 5 & 2 & 3 & 30 \\
\hline & $\# 15$ & & Sludge build up & $\begin{array}{l}\text { Scheduled } \\
\text { replacement of } \\
\text { filter }\end{array}$ & $\begin{array}{l}\text { Machine real time } \\
\text { feedback: Alarm on } \\
\text { low flowrate }\end{array}$ & 5 & 2 & 3 & 30 \\
\hline \multirow{2}{*}{$\begin{array}{l}\text { Heat } \\
\text { exchanger }\end{array}$} & $\# 16$ & $\begin{array}{l}\text { Chemical concentration } \\
\text { is out of specification }\end{array}$ & Heat exchanger leak & $\begin{array}{l}\text { Scheduled } \\
\text { replacement of } \\
\text { heat exchanger }\end{array}$ & $\begin{array}{c}\text { Chemical } \\
\text { concentration } \\
\text { Sampling analysis }\end{array}$ & 4 & 1 & 6 & 24 \\
\hline & $\# 17$ & $\begin{array}{l}\text { Dilution in the process } \\
\text { bath }\end{array}$ & Heat exchanger leak & $\begin{array}{l}\text { Scheduled } \\
\text { replacement of } \\
\text { heat exchanger }\end{array}$ & $\begin{array}{c}\text { Chemical } \\
\text { concentration } \\
\text { Sampling analysis }\end{array}$ & 4 & 1 & 6 & 24 \\
\hline
\end{tabular}


Table 5 FMEA on the HWEE components (cont.)

\begin{tabular}{|c|c|c|c|c|c|c|c|c|c|c|c|c|c|c|}
\hline \multirow[b]{2}{*}{ Component } & \multirow[b]{2}{*}{$\begin{array}{c}\text { Potential } \\
\text { Failure } \\
\text { Mode \# }\end{array}$} & \multirow[b]{2}{*}{$\begin{array}{l}\text { Potential } \\
\text { Failure } \\
\text { Mode }\end{array}$} & \multirow[b]{2}{*}{$\begin{array}{c}\text { Potential } \\
\text { Cause(s)// } \\
\text { Mechanism(s) } \\
\text { of Failure }\end{array}$} & \multicolumn{2}{|c|}{$\begin{array}{l}\text { Current Design } \\
\text { Controls }\end{array}$} & \multirow[b]{2}{*}{ 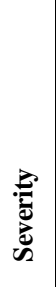 } & \multirow[b]{2}{*}{ 竎 } & \multirow[b]{2}{*}{ 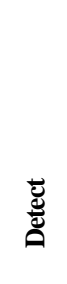 } & \multirow[b]{2}{*}{$\underline{Z}$} & \multirow[b]{2}{*}{$\begin{array}{l}\text { Corrective } \\
\text { Action(s) }\end{array}$} & \multirow[b]{2}{*}{ 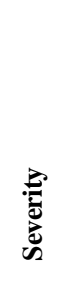 } & \multirow[b]{2}{*}{ ठั } & \multirow[b]{2}{*}{ 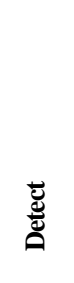 } & \multirow[b]{2}{*}{ Z } \\
\hline & & & & Prevent & Detect & & & & & & & & & \\
\hline \multirow[t]{2}{*}{ Piping } & $\# 1$ & \multirow{2}{*}{$\begin{array}{l}\text { Leaking of } \\
\text { chemical } \\
\text { from the } \\
\text { piping } \\
\text { installed at } \\
\text { the } \\
\text { equipment }\end{array}$} & $\begin{array}{l}\text { Poor welding } \\
\text { at the joint } \\
\text { area on the } \\
\text { piping }\end{array}$ & None & $\begin{array}{l}\text { Machine } \\
\text { real time } \\
\text { feedback: } \\
\text { Alarm on } \\
\text { leaking }\end{array}$ & 7 & 6 & 3 & 126 & $\begin{array}{c}\text { Conduct } \\
\text { thermal } \\
\text { stress on } \\
\text { the piping } \\
\text { and } \\
\text { improve } \\
\text { welding } \\
\text { material }\end{array}$ & 5 & 6 & 3 & 90 \\
\hline & $\# 2$ & & $\begin{array}{l}\text { Incompatible } \\
\text { piping } \\
\text { material }\end{array}$ & None & $\begin{array}{c}\text { Visual } \\
\text { inspection }\end{array}$ & 7 & 3 & 3 & 63 & N/A & N/A & N/A & N/A & N/A \\
\hline \multirow{2}{*}{ Gearbox } & $\# 3$ & $\begin{array}{l}\text { Chemical } \\
\text { penetrate } \\
\text { into the } \\
\text { gearbox }\end{array}$ & $\begin{array}{l}\text { Broken seal in } \\
\text { the gearbox }\end{array}$ & $\begin{array}{l}\text { Scheduled } \\
\text { replacement } \\
\text { of gearbox }\end{array}$ & $\begin{array}{c}\text { Visual } \\
\text { inspection }\end{array}$ & 5 & 3 & 7 & 105 & $\begin{array}{l}\text { Change the } \\
\text { seal } \\
\text { material of } \\
\text { the } \\
\text { gearbox }\end{array}$ & 5 & 2 & 7 & 70 \\
\hline & $\# 4$ & $\begin{array}{c}\text { Gearbox } \\
\text { finger } \\
\text { broken }\end{array}$ & $\begin{array}{l}\text { Friction } \\
\text { between the } \\
\text { rollers }\end{array}$ & $\begin{array}{l}\text { Scheduled } \\
\text { replacement } \\
\text { of gearbox }\end{array}$ & $\begin{array}{c}\text { Visual } \\
\text { inspection }\end{array}$ & 5 & 2 & 7 & 70 & N/A & N/A & N/A & N/A & N/A \\
\hline
\end{tabular}

Figure 6 represents the overall Risk Priority Number (RPN) for the failure modes of each of the components in the HWEE system. The highest RPN is 126 , which refers to the piping component where the potential failure mode is chemical leakage from the piping installed on the equipment. The potential cause for the failure is poor welding at the joint area of the piping. There is no control for the leak in terms of prevention, but it can be detected by an alarm on the equipment.

The gearbox has the second highest RPN at 105 where the potential failure mode is chemical penetration into the gearbox. The failure mechanism is a broken seal in the gearbox which will allow chemicals to attack or penetrate the gearbox. The recommended action for preventing or reducing the occurrence of this failure is changing the seal material to a nother suitable material which ca n protect the gearbox and withstand the chemicals. The current prevention method is by maintenance where a scheduled replacement of the gearbox is carried out every 4 years based on data collection. Gearbox failure is detected by visual inspection.

Potential failure modes with a RPN of more than 100 can be reduced to less than 100 by taking the appropriate correctiveaction. As discussed earlier in the FMEA, potential failure modes \#1 and \#3 have RPN of more than 100. Failure mode \#1 represents the piping component and the potential failure mode is leaking with an original RPN of 126 . The RPN can be reduced to 90 whereby the severity is reduced from 7 to 5 by conducting thermal stress treatment on the piping and improving the welding method and material. Fa ilure mode\# 3 refers to the gearbox component where the potential failure mode is chemical penetration into the gea rbox. Chan ging or replacing the seal material of the gearbox can reduce the RPNby reducing theoccurrence from 3 to 2 . Thus, the RPN can be reduced from 105 to 70 . 


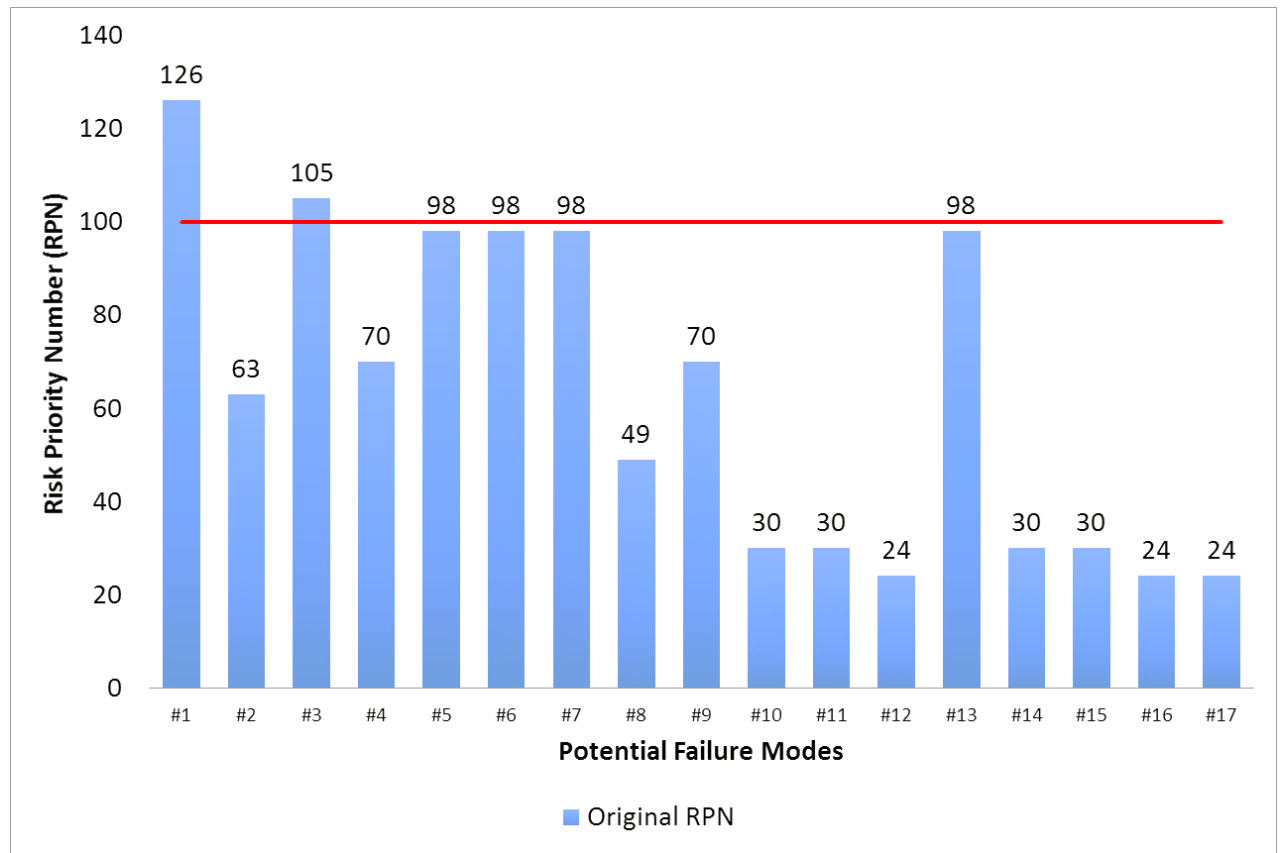

Figure 6 RPN calculated from FMEA

As discussed earlier, the RPN for potential failure modes \#1 and\#3 are reduced from 126 to 90 and 105 to 70 , respectively, as shown in Figure 7. The RPN are reduced due to the implementation of the described corrective actions. Another corrective action that might be able to reduce the RPN for piping leakage is insta lling a coupling between the joint a rea of the welding on the piping. For the gearbox, instead of replacing the seal material, a nother corrective action that can be taken is monitoring the gearbox performance using a vibration meter and defining the limits for replacement. Other potential failure modes with RPN of less than 100 do not require corrective action. The target RPN of 100 is ba sed on a common industrial target in order to achieve low RPN and higher reliability.

Therefore, by conducting FMEA, potential ha zardous im pact such as chemical leakage from the piping, human hand ling during pipe welding, and repla cing the gearbox can be minimised or avoided. It can benefit the industry in terms of achieving key performance such a s cost, productivity, and quality.

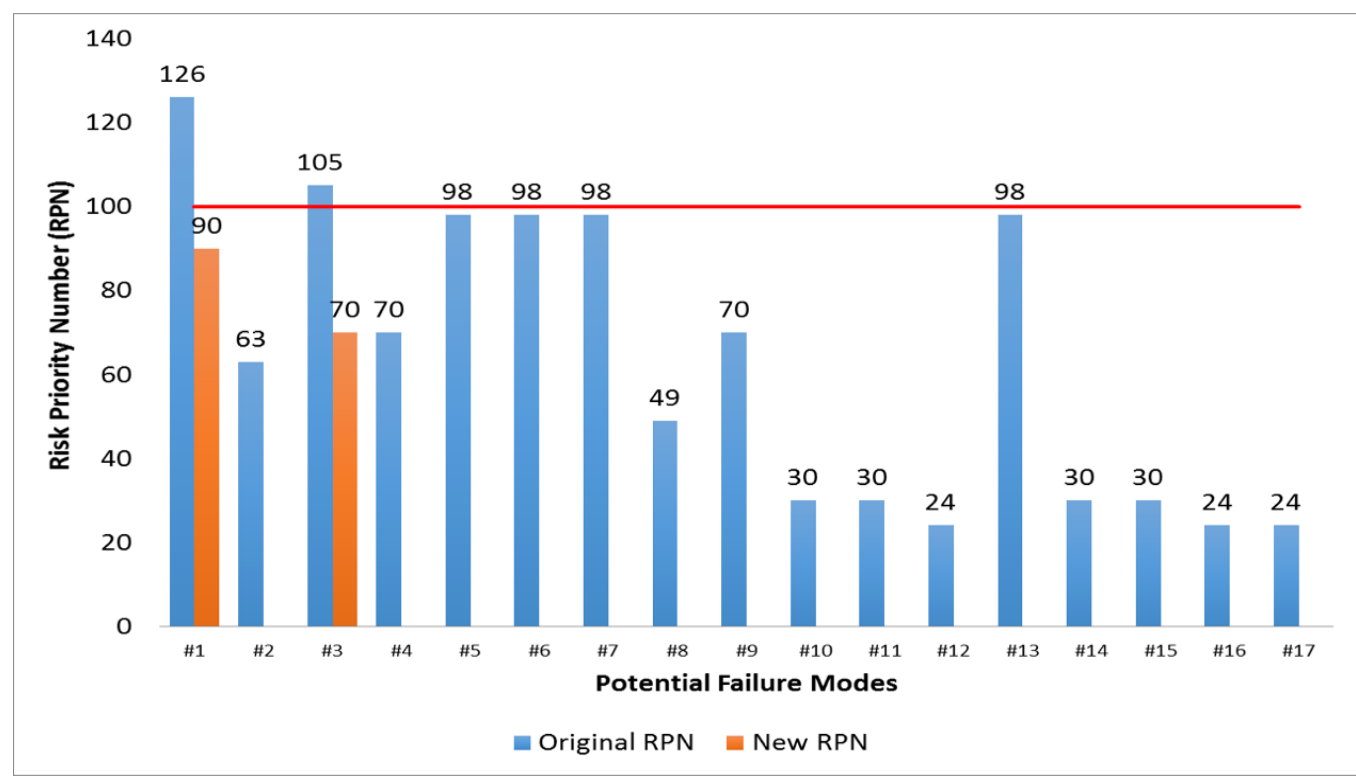

Figure 7 Comparison of original RPN and new RPN 


\section{CONCLUSION}

The critical components in the HWEE equipment are identified using MTTR and MTBF data. The reliability a ssessment of the components is carried out and the assessment shows that two components which have high relative loss are the piping and gearbox. With that, potential failure modes are identified, which show that both components have high RPN from FMEA. Corrective actions have been taken for both components in order to improve the RPN by conducting thermal stress on the piping and improving the welding method and material for the piping, while the seal material in the gearbox is replaced. The implementation of the above corrective actions could help reduce the RPN to less than 100 . Therefore, the investiga tion of the critical components has successfully identified and prevented losses in terms of maintenance cost. Among the limitation of the study is the inability to include details of the piping failure. This is due to a limitation in the metrology tool to analyse the root cause of the piping failure in the etching process equipment. In the future, an advance tool for root cause analy sis can be u sed, and thus for further reliability a ssessment.

\section{Acknowledgements}

This work was carried out with data coming from the respective High Technology Manufacturing Company, Department of Chemical \& Environmental Engineering, Universiti Putra Malaysia and Process Safety and Loss Prevention Programme. We would like to thank them all heartily.

\section{List of Abbreviations}

$\begin{array}{ll}\text { PV } & \text { Solar Photovoltaic } \\ \text { HWEE } & \text { Horizontal Wet Etching Equipment } \\ \text { FMEA } & \text { Failure Mode and Effect Analysis } \\ \text { MES } & \text { Manufacturing Execution System } \\ \text { PVDF } & \text { Polyvinylidene fluoride } \\ \text { RPN } & \text { Risk Priority Number } \\ \text { MTTR } & \text { Mean Time to Repair } \\ \text { MTBF } & \text { Mean Time between Repair } \\ \text { P\&ID } & \text { Process \& Instrumentation Diagram } \\ \text { PM } & \text { Preventive maintenance } \\ \text { PrM } & \text { Proactive maintenance } \\ \text { CbM } & \text { Condition based maintenance } \\ \text { RCM } & \text { Reliability centered maintenance }\end{array}$

\section{References}

[1] Akarslan, F. 2011. 'Photovoltaic Systems and Applications, Modelling and Optimization of Renewable Energy Systems'. Intech, Croatia.

[2] Alizadeh, S. \& Sriramula, S. 2018. Impact of Common Cause Failure on Reliability Performance of Redundant Safety Related Systems Subject to Process Demand. Reliability Engineering and System Safety. 172 (December 2017): 129-150.

[3] Hacke, P., Lokanath, S., Williams, P., Vasan, A., Sochor, P., Tamizhmani, G. \& Kurtz, S. 2018. A Status Review of Photovoltaic Power Conversion Equipment Reliability, Safety, And Quality Assurance Protocols. Renewable and Sustainable Energy Reviews. 82 (July 2017 ): $1097-1112$.

[4] Jiang, Z., Zhou, T., Zhang, H., Wang, Y., \& Cao, H. 2016. Reliability and Cost Optimization for Remanufacturing Process Planning. Journal of Cleaner Production. 135: 1602-1610.

[5] Kenneth B. 2016. 'Equipment Reliability Principles. Rethinking Bhopal, A Definitive Guide to Investigating, Preventing, and Learning from Industrial Disasters'. 21-63. Elsevier, Oxford, United Kingdom.

[6] Mauro V., Vittorio C., Lucrezia A. \& Vito I. 2017. Optimization of Photovoltaic Maintenance Plan by Means of a FMEA Approach B ased on Real Data. Journal of Energy Conversion and Management. 152: 1-12.

[7] Moinuddin, K. A. M., \& Thomas, I. R. 2014. Reliability of Sprinkler System in Australian High Rise Office Buildings. Fire Safety Journal. 63: 52-68.

[8] Nor'ain M. R. 2018. 'Failure Mechanism on Horizontal Wet Etching Equipment in High Technology Manufacturing Plant Industry'. Master in Science Thesis. Universiti Putra Malaysia. 
Nor'ain Mohd Ramli \& Siti Aslina Hussain /JEST-Joumal of Energy and Safety Technology. vol. 3, no.1 (2020):01-11

[9] Peng, D., Duh, Y. \& Shu, C. 2006. Wet Bench Reactive Hazards of Cleaning Stages in Semiconductor Manufacturing Processes. Journal of Loss Prevention in the Process Industrie. 19: 743-753.

[10] Sze, S.M. \& Ng, K.K 2006. 'Physics of Semiconductor Devices (3 ${ }^{\text {rd }}$ Edition)'. Wiley, London.

[11] Vishnu, C. R. \& Regikumar, V. 2016. Reliability Based Maintenance Strategy Selection in Process Plants : A Case Study. Procedia Technology. 25: 1080-1087.

[12] Yasaad, B., Khiat, M. \& Chaker, A. 2014. Electrical Power and Energy Systems Reliability Centered Maintenance Optimization For Power Distribution Systems. International Journal of Electrical Power and Energy Systems. 55: 108-115.

[13] Karaven Ali, \& Vasili, Mohamamreza \& Maji, 2018. Improving Maintenance Strategies by Increasing Equipment Reliability at the Design Phase.

[14] Maintainability, Availability, Reliability and Operability Simulation program (MAROS), 2016, Version no 9.03.01.1043, DNV-GL, Norway. 